\title{
Increased protein content of chickpea (Cicer arietinum L.) inoculated with arbuscular mycorrhizal fungi and nitrogen-fixing bacteria under water deficit conditions
}

\author{
Rui S Oliveira, ${ }^{\mathrm{a}, \mathrm{b}^{*}}$ Patrícia Carvalho, ${ }^{\mathrm{b}}$ Guilhermina Marques, ${ }^{\mathrm{c}}$ Luís Ferreira, ${ }^{\mathrm{d}}$ \\ Mafalda Nunes, ${ }^{b}$ Inês Rocha, ${ }^{a}$ Ying Ma, ${ }^{a}$ Maria F Carvalho, \\ Miroslav Vosátka ${ }^{\mathrm{f}, \mathrm{g}}$ and Helena Freitas ${ }^{\mathrm{a}}$
}

\begin{abstract}
BACKGROUND: Chickpea (Cicer arietinum L.) is a widely cropped pulse and an important source of proteins for humans. In Mediterranean regions it is predicted that drought will reduce soil moisture and become a major issue in agricultural practice. Nitrogen (N)-fixing bacteria and arbuscular mycorrhizal (AM) fungi have the potential to improve plant growth and drought tolerance. The aim of the study was to assess the effects of $\mathrm{N}$-fixing bacteria and AM fungi on the growth, grain yield and protein content of chickpea under water deficit.
\end{abstract}

RESULTS: Plants inoculated with Mesorhizobium mediterraneum or Rhizophagus irregularis without water deficit and inoculated with $M$. mediterraneum under moderate water deficit had significant increases in biomass. Inoculation with microbial symbionts brought no benefits to chickpea under severe water deficit. However, under moderate water deficit grain crude protein was increased by $13 \%, 17 \%$ and $22 \%$ in plants inoculated with $M$. mediterraneum, R. irregularis and M. mediterraneum + R. irregularis, respectively.

CONCLUSION: Inoculation with $\mathrm{N}$-fixing bacteria and AM fungi has the potential to benefit agricultural production of chickpea under water deficit conditions and to contribute to increased grain protein content.

Keywords: drought; grain legume; grain protein content; Mesorhizobium mediterraneum; Rhizophagus irregularis

\section{INTRODUCTION}

Chickpea (Cicer arietinum L.) is the second most important legume crop consumed worldwide, especially in North Africa, South-East Asia, the Middle East, southern Europe, America and Australia. ${ }^{1}$ Globally, it is one of the most cultivated pulses in terms of world production, with a total production of 14.2 million $t$ and an average yield of $0.96 \mathrm{t} \mathrm{ha}^{-1}$. $^{2}$ Chickpea has been considered an important source of proteins, carbohydrates, minerals, vitamins and health-promoting fatty acids in the human diet., ${ }^{3,4}$ As a cheaper source of protein it is particularly important for low-income consumers around the world and in developing countries, where large segments of populations have limited access to food of animal origin. ${ }^{5}$ Chickpea is usually cultivated in regions where climate variability, drought and limited use of fertilizers significantly reduce productivity. However, being a leguminous crop, it exhibits the important characteristic of fixing atmospheric nitrogen $(\mathrm{N})$ through its symbiosis with rhizobia, enabling cultivation in many $\mathrm{N}$-poor soils with acceptable yields. Chickpea rhizobia are included in the Mesorhizobium genus ${ }^{4}$ and can fix up to $140 \mathrm{~kg} \mathrm{~N} \mathrm{ha}^{-1}$ per annum, depending on soil and climatic conditions. $^{6}$ *orrespondence to: RS Oliveira, Centre for Functional Ecology, Department of Life Sciences, University of Coimbra, Calçada Martim de Freitas, 3000-456 Coimbra, Portugal.E-mail: rsoliveira@uc.pt

a Centre for Functional Ecology, Department of Life Sciences, University of Coimbra, Coimbra, Portugal

b Department of Environmental Health, Research Centre on Health and Environment, School of Allied Health Sciences, Polytechnic Institute of Porto, Porto, Portugal

c University of Trás-os-Montes e Alto Douro, Centre for the Research and Technology of Agro-Environmental and Biological Sciences (UTAD-CITAB), Vila Real, Portugal

d Animal and Veterinary Research Centre (CECAV), University of Trás-os-Montes and Alto Douro (UTAD), Vila Real, Portugal

e CIIMAR - Interdisciplinary Centre of Marine and Environmental Research, University of Porto, Matosinhos, Portugal

$f$ Institute of Botany, Academy of Sciences of the Czech Republic, Prühonice, Czech Republic

g Department of Experimental Plant Biology, Charles University, Faculty of Science, Viničná 5, Praha 2, Czech Republic 
Legume plants also establish mutualistic relationships with arbuscular mycorrhizal (AM) fungi, which together with rhizobia are often designated by tripartite symbioses. ${ }^{7,8}$ The environmental benefits of legumes are the reduced use of mineral $\mathrm{N}$ fertilizer, ${ }^{9,10}$ the improvement of soil conditions and the yield increase of succeeding crops in the rotation. ${ }^{11,12}$ Relatively few studies have addressed the influence of AM fungi in the performance of legume-rhizobia symbiosis. Nevertheless, benefits of AM fungi have been demonstrated on legume growth, $\mathrm{N}$ fixation, grain yield, ${ }^{13,14}$ plant uptake of nutrients, ${ }^{15-17}$ hormonal balance and water relations. ${ }^{18,19}$

In Mediterranean regions drought stress is known to hamper plant production. ${ }^{20}$ In legumes, drought has a considerable negative impact on nodule functioning, due to premature senescence and consequent reduction of $\mathrm{N}$ fixation. ${ }^{21}$ It has been demonstrated that AM fungi can efficiently alleviate drought stress by several mechanisms, including regulation of plant hormonal balance, ${ }^{22}$ increased photosynthetic rate and leaf gas exchange, ${ }^{23}$ and translocation of water from soil to plant via extraradical mycelium (ERM). ${ }^{24,25}$ Since prolonged periods of drought are responsible for yield losses, optimization of the relationships of legumes with drought-tolerant microbial symbionts is required to develop effective methods for minimizing the effects of exposure to drought.

The aims of the present study were (i) to determine the effects of an $\mathrm{N}$-fixing bacterium and an AM fungus on the growth and grain yield of chickpea under three different water regimes, and (ii) to assess whether microbial inoculation could improve grain protein content, particularly under water deficit.

\section{MATERIALS AND METHODS}

\section{Plant material and soil}

The seeds used in this study were from chickpea (Cicer arietinum L. cv. Chk 4198) obtained from the collection of UTAD. Soil was collected from the uppermost $10 \mathrm{~cm}$ layer of an organic farm in northern Portugal, sieved through a $4 \mathrm{~mm}$ mesh and autoclaved twice $\left(121^{\circ} \mathrm{C}\right.$ for $25 \mathrm{~min}$ ) on consecutive days. This was a sandy soil with $\mathrm{pH}\left(1: 2.5 \mathrm{w} / \mathrm{v}\right.$ water) 6.5 , electrical conductivity $0.1 \mathrm{dS} \mathrm{m}^{-1}$, $1.2 \%$ organic matter, $3.8 \mathrm{~g} \mathrm{~kg}^{-1}$ total $\mathrm{N}, 48.8 \mathrm{mg} \mathrm{kg}^{-1}$ extractable (Egner-Riehm) P, $4.3 \mathrm{~g} \mathrm{~kg}^{-1} \mathrm{~K}, 1.6 \mathrm{~g} \mathrm{~kg}^{-1} \mathrm{Ca}, 66 \mathrm{mg} \mathrm{kg}^{-1} \mathrm{Mg}$ and $147 \mathrm{mg} \mathrm{kg}^{-1} \mathrm{Na}$.

\section{Microbial inocula}

The bacterial isolate Mesorhizobium mediterraneum UPM-Ca36 was grown in Tryptone Yeast (TY) medium ${ }^{26}$ for 3 days at $28^{\circ} \mathrm{C}$ and $0.5 \times g$. The culture was then centrifuged at $4930 \times g$ for $10 \mathrm{~min}$ and the pellet was washed with saline solution $(0.85 \% \mathrm{NaCl})$. The pellet was resuspended in saline solution and the colony-forming unit (CFU) adjusted to $10^{9} \mathrm{~mL}^{-1}$.

The AM fungal isolate Rhizophagus irregularis BEG140 was grown for 8 months in a multi-spore pot culture containing a 1:1 (v/v) mixture of zeolite and expanded clay with Zea mays L. as a host plant. The fungal inoculum was provided by Symbiom Ltd, Czech Republic.

\section{Experimental design and setup}

Experimental units ( $1 \mathrm{dm}^{3}$ pots filled with soil) were arranged in a fully randomized manner using a $2 \times 2 \times 3$ factorial design, where the first factor was bacterial inoculation (non-inoculated plants and plants inoculated with $M$. mediterraneum), the second factor was fungal inoculation (non-inoculated plants and plants inoculated with $R$. irregularis) and the third factor was water deficit (no water deficit $(\mathrm{N})$, moderate water deficit $(\mathrm{M})$ and severe water deficit $(S)$ ). Thus for each water regime there were four treatments: non-inoculated plants; plants inoculated with M. mediterraneum; plants inoculated with $R$. irregularis; and dually inoculated plants. Each treatment combination was replicated 10 times. Seeds of chickpea were surface sterilized with $0.5 \%(\mathrm{v} / \mathrm{v})$ sodium hypochlorite for $20 \mathrm{~min}$, placed on moist paper towels and germinated at $20^{\circ} \mathrm{C}$ in the dark. After germination, seedlings of similar size were transplanted: one plant into each pot. A nitrocellulose membrane filter ( $24 \mathrm{~mm}$ diameter and $0.4 \mu \mathrm{m}$ pore size) (Pragopore, Pragochema Ltd, Czech Republic) was inserted vertically into each pot for future measurements of ERM length. ${ }^{27}$ At transplanting, each pot from the bacterial treatments received $4 \mathrm{~mL}$ bacterial suspension (described above). Every pot from the non-bacterial treatments received $4 \mathrm{~mL}$ autoclaved bacterial suspension. Each pot from the mycorrhizal treatments received $10 \mathrm{~g}$ inoculum consisting of colonized root fragments, hyphae and spores in the mixture of zeolite and expanded clay, placed $2 \mathrm{~cm}$ below the root system. Every pot from the non-mycorrhizal treatments received $10 \mathrm{~g}$ inoculum autoclaved twice $\left(121^{\circ} \mathrm{C}\right.$ for $\left.25 \mathrm{~min}\right)$ on consecutive days. In order to eliminate differences in bacterial populations introduced with the AM fungal inoculum, $5 \mathrm{~mL}$ of a filtrate of AM fungal inoculum was added to all pots from the non-mycorrhizal treatments. ${ }^{28}$ The filtrate was prepared as described in Oliveira et al..$^{29}$ Field capacity of the soil in the pots was determined ${ }^{30}$ and during the first 4 weeks soil moisture in all pots was kept at $75 \%$ of field capacity by weighing the pots every 2 days and watering accordingly with deionized water. Then soil moisture was kept at $75 \%, 50 \%$ and $25 \%$ of field capacity by weighing the pots for the treatments with no water deficit, moderate water deficit and severe water deficit, respectively. Plants were grown in a greenhouse under natural light with an average photoperiod of $12 \mathrm{~h}$. Temperature and relative humidity ranges were $12-42{ }^{\circ} \mathrm{C}$ and $55-85 \%$, respectively. Pots of different treatments were periodically rotated to different bench positions to minimize differences due to their location in the greenhouse.

\section{Plant and microbial analyses}

After a growth period of 3 months, grains were harvested and the number of grains per plant, fresh weight of grains per plant and fresh weight per grain were determined. Grain samples were dried at $80^{\circ} \mathrm{C}$ for $48 \mathrm{~h}$ and analysed for total Kjeldahl $\mathrm{N}$ following the methods of the Association of Official Analytical Chemists. ${ }^{31}$ Crude protein was calculated as $\mathrm{N} \times 6.25$. $^{32}$ Plants were removed from the pots, and the root system was separated from the shoot and gently washed to remove adhered soil. Shoot height was measured and the number of root nodules was counted. A fresh subsample $(0.2 \mathrm{~g})$ of roots was collected to assess AM colonization (described below). The remaining root system was weighed and dried at $80^{\circ} \mathrm{C}$ for $48 \mathrm{~h}$ together with the shoot. The dried root system and shoot were then reweighed. The dry root mass of the subsample was calculated by multiplying its fresh mass by the dry-to-fresh mass ratio of the root system. The sum of the dry mass of the root subsample with the dry mass of the root system and the dry mass of the shoot gave the total dry weight per plant. The subsample of fresh roots was cut into $1 \mathrm{~cm}$ pieces and stained with trypan blue using a modified Phillips and Hayman ${ }^{33}$ protocol. ${ }^{34}$ Percentage root length colonized (RLC) by AM fungi was assessed for each plant species using the gridline intersect method ${ }^{35}$ under a stereo microscope (Olympus SZ61, Japan). The ERM length was determined by the 


\begin{tabular}{|c|c|c|c|c|}
\hline & Shoot height & Root dry weight & Shoot dry weight & Total plant dry weight \\
\hline Bacterial inoculation (B) & $2.1 \mathrm{~ns}$ & $1.4 \mathrm{~ns}$ & $3.6 \mathrm{~ns}$ & $2.9 \mathrm{~ns}$ \\
\hline Fungal inoculation (F) & $36.4^{* * *}$ & $0.01 \mathrm{~ns}$ & $10.3^{* *}$ & $1.1 \mathrm{~ns}$ \\
\hline Water deficit (W) & $12.8^{* * *}$ & $2.0 \mathrm{~ns}$ & $14.8^{* * *}$ & $5.6^{* *}$ \\
\hline$B \times F$ & $0.1 \mathrm{~ns}$ & $7.6^{* *}$ & $2.7 \mathrm{~ns}$ & $6.8^{*}$ \\
\hline$B \times W$ & $1.4 \mathrm{~ns}$ & $0.9 \mathrm{~ns}$ & $1.3 \mathrm{~ns}$ & $0.7 \mathrm{~ns}$ \\
\hline $\mathrm{F} \times \mathrm{W}$ & $0.2 \mathrm{~ns}$ & $1.3 \mathrm{~ns}$ & $0.01 \mathrm{~ns}$ & $0.6 \mathrm{~ns}$ \\
\hline$B \times F \times W$ & $0.4 \mathrm{~ns}$ & $0.3 \mathrm{~ns}$ & $3.1 \mathrm{~ns}$ & $0.8 \mathrm{~ns}$ \\
\hline
\end{tabular}

inserted membrane technique ${ }^{27}$ followed by the gridline intersect method under a compound microscope (Leica DM 750, Germany), using an ocular grid at $\times 200$ magnification. ${ }^{36}$ Background lengths of mycelium found in non-mycorrhizal treatments were subtracted from the values obtained in the corresponding mycorrhizal treatments and the ERM length expressed in $\mathrm{cm}$ of hyphae per $1 \mathrm{~cm}^{2}$ of the inserted membrane filter.

\section{Statistical analysis}

Normality and homogeneity of variances were confirmed and data analysed using three-way analysis of variance (ANOVA) for each dependent variable (plant parameters) versus independent variables (bacterial inoculation, fungal inoculation and water deficit). When a significant $F$-value was obtained $(P<0.05)$, treatment means were compared using Duncan's multiple range test. Microbial parameters data were analysed by two-way ANOVA without including the respective non-inoculated control treatments. All statistical analyses were performed with the SPSS 23.0.0.0 software package (IBM SPSS Statistics, USA).

\section{RESULTS AND DISCUSSION Plant growth}

Single inoculation with the AM fungus $R$. irregularis significantly increased shoot height of chickpea in all water regimes when compared with the respective non-inoculated controls (Fig. 1A). Tufenkci et al. ${ }^{37}$ also showed that inoculation with an AM fungal isolate resulted in higher shoot height of chickpea. However, in their study water deficit was not imposed to the plants. Dually inoculated ( $M$. mediterraneum $+R$. irregularis) plants had significantly higher shoot height than non-inoculated controls under moderate water deficit (M). There was no effect on shoot height of single inoculation with the $\mathrm{N}$-fixing bacterium $M$. mediterraneum (Table 1). Water deficit significantly influenced shoot height of chickpea, particularly in non-inoculated control plants where increased water deficit significantly decreased shoot height; in plants inoculated with $R$. irregularis where moderate water deficit significantly reduced shoot height in comparison with plants without water deficit; and in dually inoculated plants where severe water deficit $(S)$ resulted in a reduction of shoot height of chickpea when compared with plants without water deficit. Reduced irrigation in order to maintain severe water stress was shown to be detrimental to the growth of chickpea, since a reduction in plant height under such conditions has been reported. ${ }^{38}$

Overall there was no significant effect of bacterial inoculation, fungal inoculation and water deficit on the dry weight of roots of chickpea (Table 1). The exception was in plants inoculated with $M$. mediterraneum and subjected to moderate water deficit, where root dry weight was significantly greater than the respective non-inoculated control (Fig. 1B).

Under severe water deficit there were no significant differences in shoot dry weight between non-inoculated controls and all inoculation treatments, whereas without water deficit all inoculations (single and dual) resulted in significantly improved shoot dry weight of chickpea (Fig. 1C). Additionally, dually inoculated plants subjected to moderate water deficit also had significantly improved shoot dry weight compared with non-inoculated control. Significant reductions in shoot dry weight of singly and dually inoculated chickpea were observed in plants under severe water deficit in comparison with those without water deficit.

Inoculation with $R$. irregularis was shown to significantly improve total biomass of chickpea without water deficit. Plants inoculated with $M$. mediterraneum without water deficit and under moderate water deficit had higher biomass than the corresponding noninoculated controls (Fig. 1D). Under severe water deficit there were no significant differences in total plant dry weight between noninoculated control plants and those of any inoculation treatment.

$\mathrm{N}$-fixing bacteria and AM fungi have the potential to improve plant growth and alleviate drought stress under water-limiting conditions. ${ }^{39-46}$ Considering such potential, we aimed at assessing whether inoculation with M. mediterraneum and $R$. irregularis could improve plant growth, grain yield and protein content under water deficit.

Our results showed that shoot height was increased by inoculation with $R$. irregularis under moderate and severe water deficit and by inoculation with $M$. mediterraneum $+R$. irregularis under moderate water deficit, whereas plant biomass was only improved in plants inoculated with $M$. mediterraneum under moderate water deficit.

Erman et al. ${ }^{47}$ reported improved plant biomass of chickpea grown without irrigation and inoculated singly and dually with AM fungi and N-fixing bacteria. The authors suggested that both bipartite and tripartite symbioses contributed to better plant nutrition, particularly regarding $\mathrm{N}$ and $\mathrm{P}$, which resulted in improved plant growth. Enhanced nutrient uptake in inoculated chickpea has also been demonstrated by Farzaneh and colleagues. ${ }^{15}$

There was no AM fungal colonization or nodules of $M$. mediterraneum in the roots of non-inoculated control plants. All plants inoculated with $R$. irregularis had root mycorrhizal colonization and all plants inoculated with $M$. mediterraneum developed root nodules (Table 2). Inoculation with $R$. irregularis resulted in a \%RLC that, among treatments, varied between $21 \%$ and $52 \%$, which is within the range reported by Tavasolee et al. ${ }^{48}$ for chickpea. 

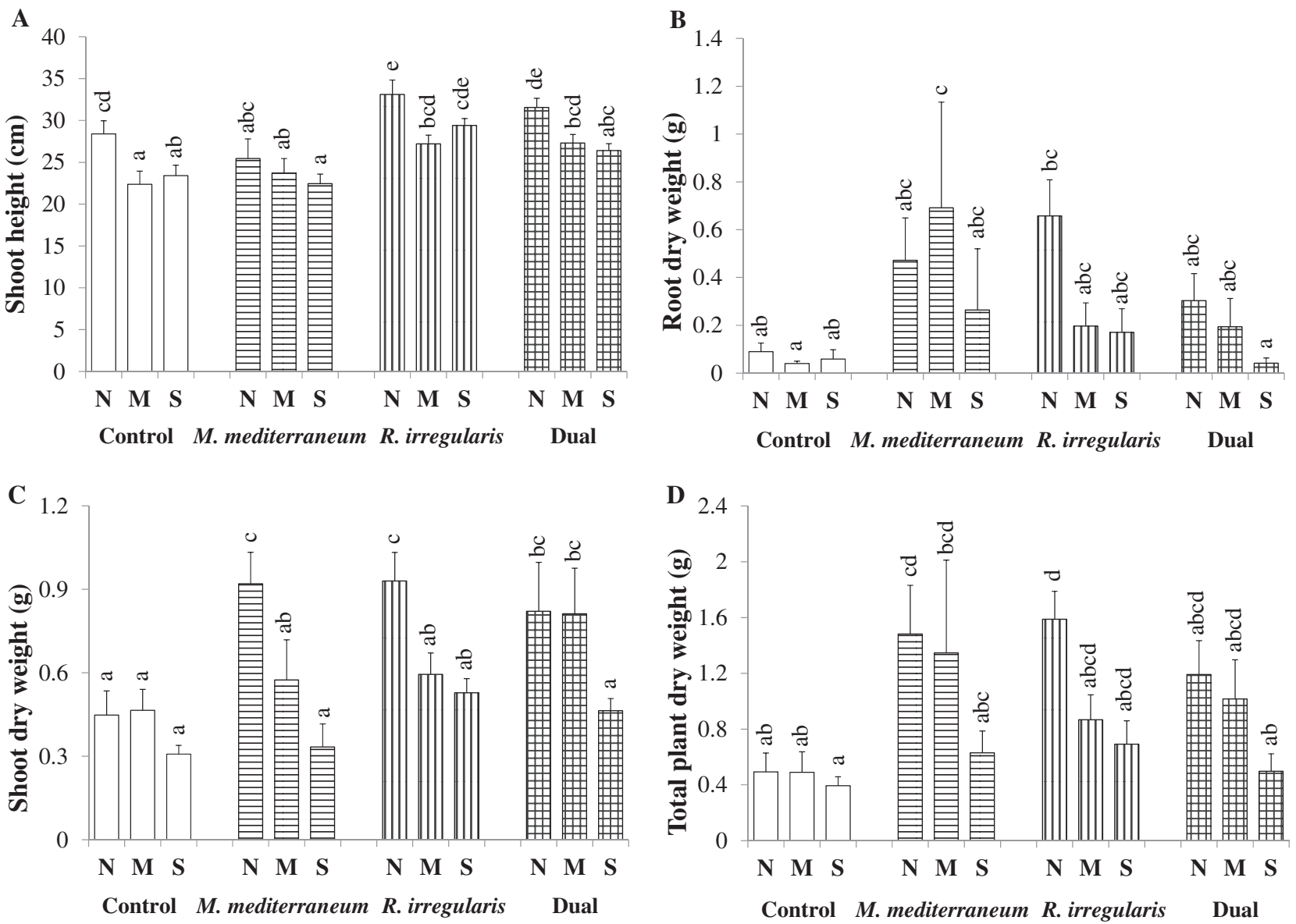

Figure 1. Shoot height (A), root (B), shoot (C) and total plant (D) dry weight of Cicer arietinum inoculated singly or dually with Mesorhizobium mediterraneum and Rhizophagus irregularis under different water deficits. Values are means $\pm 1 \mathrm{SE}$. Columns marked with different letters are significantly different according to Duncan's multiple range test at $P<0.05$. N, no water deficit; $\mathrm{M}$, moderate water deficit; S, severe water deficit.

The number of root nodules was significantly reduced in plants under severe water deficit when compared with those without water deficit. Erman et al. ${ }^{47}$ showed that without irrigation the number of nodules was significantly reduced in the roots of chickpea. Drought may reduce the number of nodules, which can negatively affect symbiosis. It seems, therefore, that severe water deficit was detrimental to the microbial symbionts, which may have contributed to the less evident plant growth benefits observed under severe than moderate water deficit. This is in agreement with the findings of Ruiz-Lozano et al., ${ }^{21}$ who demonstrated that drought has a considerable negative impact on nodule functioning, resulting in decreased ability of $\mathrm{N}$ fixation. Inoculation with $R$. irregularis did not influence the number of root nodules. There was no effect of bacterial inoculation or water deficit on the ERM length.

\section{Grain yield and protein content}

There was a significant increase in the number of grains produced per plant of chickpea with inoculation of $R$. irregularis and $M$. mediterraneum $+R$. irregularis without water deficit (Fig. 2A). However, under moderate and severe water deficit there was no increase in number of grains in any inoculation treatment when compared with the respective non-inoculated controls. Water deficit significantly influenced the number of grains per plant (Table 3). In all inoculation treatments, the number of grains per plant was significantly reduced in plants under moderate and severe water deficit when compared with those without water deficit (Fig. 2A).
Similarly, the weight of grains per plant was significantly reduced in plants under moderate and severe water deficit when compared with those without water deficit in all inoculation treatments (Fig. 2B). Additionally, a significant reduction in weight of grains per plant was observed in non-inoculated control plants under severe water deficit when compared with those without water deficit. A significant increase in weight of grains per plant of singly and dually inoculated chickpea was only observed in plants without water deficit. These observations are in agreement with the findings of Erman et al., ${ }^{47}$ who reported that both single and dual inoculation of chickpea with Mesorhizobium ciceri and Glomus intraradices resulted in increased grain yield. Zaidi et al. ${ }^{49}$ also showed that dual inoculation with an $\mathrm{N}$-fixing bacterium and an AM fungus led to increased grain yield of chickpea.

There was no influence of any inoculation treatment in the weight per grain of chickpea (Table 3). However, in plants inoculated with $M$. mediterraneum there was a significant reduction in the weight per grain of plants under severe water deficit when compared with those without water deficit (Fig. 2C).

Under moderate and severe water deficit there were no improvements of single or dual inoculation on grain yield. However, in plants without water deficit and in those under moderate water deficit, dual and single inoculation resulted in significant increases of the content of crude protein of chickpea grains in comparison with the respective non-inoculated controls (Fig. 2D). There were no significant differences in the content of crude protein 


\begin{tabular}{|c|c|c|c|c|}
\hline Inoculation & Water deficit & No. of nodules & AMF colonization (\%RLC) & ERM length $\left(\mathrm{cm} \mathrm{cm}^{-2}\right)$ \\
\hline \multirow[t]{3}{*}{ Mesorhizobium mediterraneum } & $\mathrm{N}$ & $27.6 \pm 3 \mathrm{~cd}$ & 0 & 0 \\
\hline & M & $20.6 \pm 3 a b c$ & 0 & 0 \\
\hline & $\mathrm{S}$ & $14.8 \pm 2 \mathrm{a}$ & 0 & 0 \\
\hline \multirow[t]{3}{*}{ Rhizophagus irregularis } & $\mathrm{N}$ & 0 & $48 \pm 5 b c$ & $15 \pm 6$ \\
\hline & M & 0 & $33 \pm 5 a b$ & $15 \pm 5$ \\
\hline & $\mathrm{S}$ & 0 & $52 \pm 8 c$ & $5 \pm 2$ \\
\hline \multirow[t]{3}{*}{ Mesorhizobium mediterraneum + Rhizophagus irregularis } & $\mathrm{N}$ & $32.2 \pm 3 d$ & $35 \pm 7 a b c$ & $17 \pm 9$ \\
\hline & M & $25.2 \pm 2 \mathrm{bcd}$ & $31 \pm 5 a b$ & $16 \pm 5$ \\
\hline & $\mathrm{S}$ & $19.8 \pm 1 \mathrm{ab}$ & $21 \pm 2 a$ & $13 \pm 4$ \\
\hline \multicolumn{5}{|l|}{ Two-way ANOVA F-values and significance } \\
\hline \multicolumn{2}{|l|}{ Bacterial inoculation (B) } & & $10.9^{* *}$ & $0.5 \mathrm{~ns}$ \\
\hline \multicolumn{2}{|l|}{ Fungal inoculation (F) } & $6.1^{*}$ & & \\
\hline \multicolumn{2}{|l|}{ Water deficit (W) } & $14.5^{* * *}$ & $1.4 \mathrm{~ns}$ & $0.9 \mathrm{~ns}$ \\
\hline \multicolumn{2}{|l|}{$B \times W$} & & $3.2 \mathrm{~ns}$ & $0.2 \mathrm{~ns}$ \\
\hline \multicolumn{2}{|l|}{$\mathrm{F} \times \mathrm{W}$} & $0.005 \mathrm{~ns}$ & & \\
\hline \multicolumn{5}{|c|}{$\begin{array}{l}\text { Means ( } \pm 1 \mathrm{SE} \text { ) followed by the same letters within each column are not significantly different according to Duncan's multiple range test; asterisks } \\
\text { indicate a significant effect at the level of }{ }^{*} P<0.05,{ }^{* *} P<0.01 \text { and }{ }^{* * *} P<0.001 \text {, respectively; } \mathrm{n} \text {, non-significant effect. } \\
\text { AMF, arbuscular mycorrhizal fungal; RLC, root length colonized; ERM, extraradical mycelium; N, no water deficit; M, moderate water deficit; } \mathrm{S} \text {, severe } \\
\text { water deficit. }\end{array}$} \\
\hline
\end{tabular}

Table 3. F-values and three-way ANOVA significance of grain parameters according to bacterial inoculation, fungal inoculation and water deficit

\begin{tabular}{|c|c|c|c|c|}
\hline & Number of grains per plant & Fresh weight of grains per plant & Fresh weight per grain & Crude protein of grains \\
\hline Bacterial inoculation (B) & $0.5 \mathrm{~ns}$ & $1.2 \mathrm{~ns}$ & $1.1 \mathrm{~ns}$ & $5.8^{*}$ \\
\hline Fungal inoculation (F) & $3.3^{*}$ & $1.0 \mathrm{~ns}$ & $0.7 \mathrm{~ns}$ & $24.2^{* * *}$ \\
\hline Water deficit (W) & $14.4^{* * *}$ & $55.1^{* * *}$ & $8.5^{* * *}$ & $8.4^{* *}$ \\
\hline$B \times F$ & $1.0 \mathrm{~ns}$ & $1.5 \mathrm{~ns}$ & $0.004 \mathrm{~ns}$ & $4.5^{*}$ \\
\hline$B \times W$ & $0.6 \mathrm{~ns}$ & $3.0 \mathrm{~ns}$ & $0.7 \mathrm{~ns}$ & $3.7^{*}$ \\
\hline $\mathrm{F} \times \mathrm{W}$ & $0.5 \mathrm{~ns}$ & $0.5 \mathrm{~ns}$ & $1.4 \mathrm{~ns}$ & $0.4 \mathrm{~ns}$ \\
\hline$B \times F \times W$ & $1.1 \mathrm{~ns}$ & $3.4^{*}$ & $0.9 \mathrm{~ns}$ & $2.7 \mathrm{~ns}$ \\
\hline
\end{tabular}

of grains between inoculated (singly and dually) plants and non-inoculated controls under severe water deficit. Under moderate water deficit inoculation with $M$. mediterraneum, $R$. irregularis and $M$. mediterraneum $+R$. irregularis led to increase in the content of crude protein of chickpea grains of $13 \%, 17 \%$ and $22 \%$, respectively. An increase in grain protein content of chickpea inoculated with AM fungi has also been reported by Pellegrino and Bedini. ${ }^{50}$ The authors speculated that the increase could have been related to the larger ERM length of AM fungi, which can improve inorganic and organic soil $\mathrm{N}$ mobilization. However, this was not clear in our study, since we not only obtained grain protein increases in plants inoculated with $R$. irregularis, where abundant ERM was observed, but also in plants inoculated with $M$. mediterraneum, where no AM fungal ERM was present (Table 2).

Grains of chickpea are highly valued for human consumption owing to their high level of protein and adequate proportions of carbohydrates and oil. ${ }^{51}$ Therefore, increases in grain protein content, as shown in our study, can be of importance for agricultural production of chickpea. Overall, grain yield was higher without water deficit. Microbial inoculation further improved grain yield. With the rise of global temperatures, extreme summer heat and prolonged drought will reduce soil moisture and become a major issue in agricultural practice..$^{20,52}$ Our results showed that inoculation with an $\mathrm{N}$-fixing bacterium and an AM fungus can contribute to improve the quality of chickpea grains under moderate water deficit.

\section{CONCLUSIONS}

Inoculation with $R$. irregularis and M. mediterraneum $+R$. irregularis increased grain productivity of chickpea without water deficit. However, under moderate and severe water deficit there was no improvement of grain yield in inoculated plants. Water availability is predicted to become a major constraint for agriculture under the warmer, drier climate of the future. Thus there is a need to improve the productivity of chickpea under drought conditions. Inoculation with $M$. mediterraneum, R. irregularis and M. mediterraneum $+R$. irregularis was shown to increase the content of crude protein of chickpea grains under moderate water deficit conditions. Additionally, there was an increase in biomass of plants inoculated with $R$. irregularis or M. mediterraneum without water deficit and inoculated with $M$. mediterraneum under moderate water deficit. $\mathrm{N}$-fixing bacteria and $\mathrm{AM}$ fungi alone and in combination have great potential to benefit the agricultural production of chickpea under adverse environmental conditions, contributing to improve food quality leading, ultimately, to benefits in human health. 

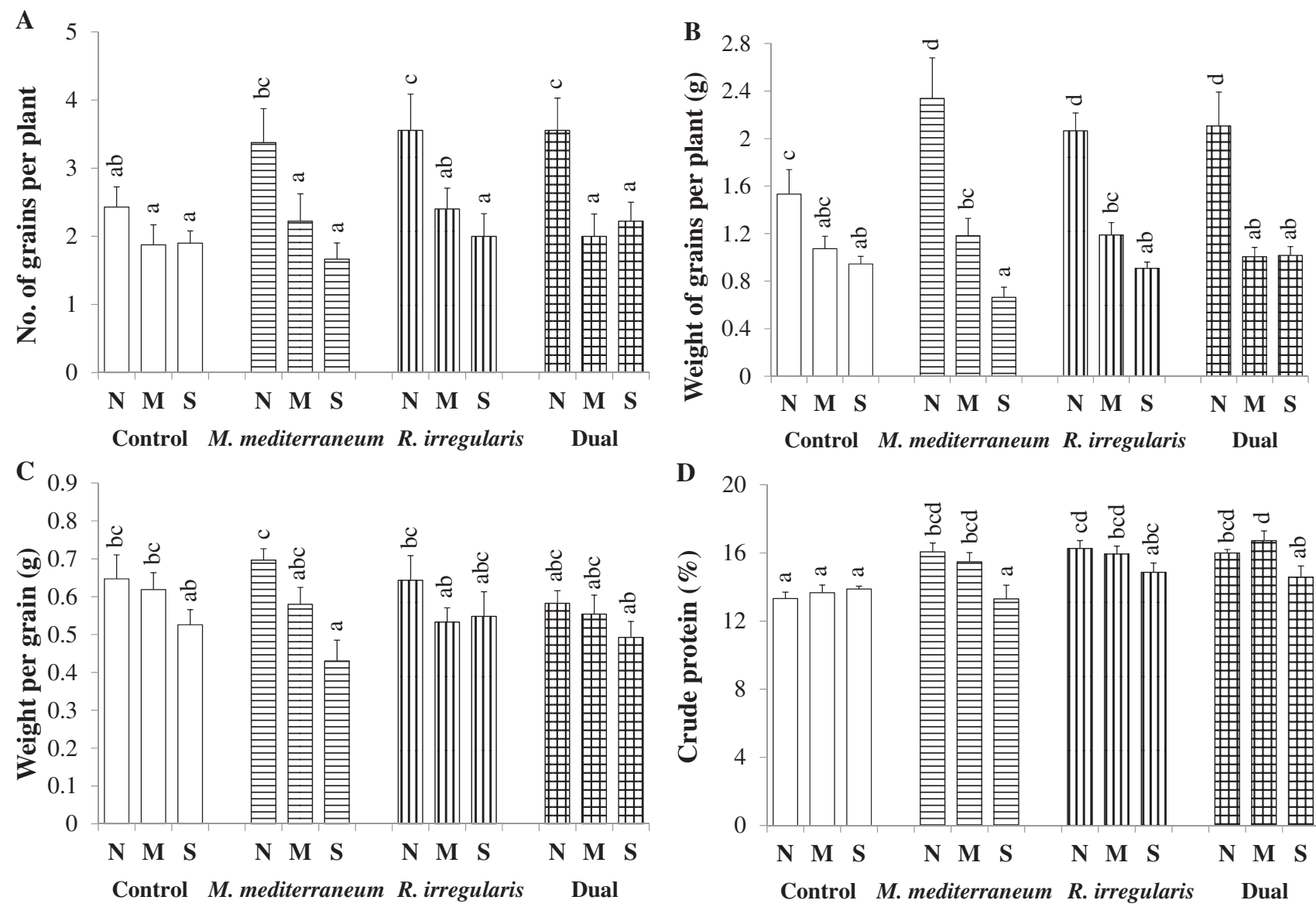

Figure 2. Number of grains per plant (A), fresh weight of grains per plant (B), fresh weight per grain (C) and percentage of crude protein of grains (D) at harvest of Cicer arietinum inoculated singly or dually with Mesorhizobium mediterraneum and Rhizophagus irregularis under different water deficits. Values are means $\pm 1 \mathrm{SE}$. Columns marked with different letters are significantly different according to Duncan's multiple range test at $P<0.05$. $\mathrm{N}$, no water deficit; $\mathrm{M}$, moderate water deficit; $\mathrm{S}$, severe water deficit.

\section{ACKNOWLEDGEMENTS}

RS Oliveira, Y Ma and I Rocha acknowledge the support of Fundação para a Ciência e a Tecnologia (FCT) through the research grants SFRH/BPD/85008/2012, SFRH/BPD/76028/2011 and SFRH/BD/100484/2014, Fundo Social Europeu (FSE) and Programa Operacional do Capital Humano (POCH). This work was financed by Portuguese national funds through Programa Operacional Competitividade e Internacionalização (POCI), Project 3599 - Promover a Produção Científica e Desenvolvimento Tecnológico e a Constituição de Redes Temáticas (3599-PPCDT) and Fundo Europeu de Desenvolvimento Regional (FEDER) under Project POCl-01-0145-FEDER-016801 and by FCT under Project PTDC/AGR-TEC/1140/2014. G Marques acknowledges the European Union's Seventh Framework Programme for research, technological development and demonstration under grant agreement no. 613781 (EUROLEGUME). M Vosátka was supported by the project NPUI LO1417 of the Ministry of Education, Youth and Sports of the Czech Republic. We thank Solange Oliveira for providing the bacterial strain.

\section{REFERENCES}

1 Iqbal A, Ateeq N, Khalil IA, Perveen S and Saleemullah S, Physicochemical characteristics and amino acid profile of chickpea cultivars grown in Pakistan. J Foodservice 17:94-101 (2006).
2 FAOSTAT, Food and Agriculture Organization of the United Nations, Statistics Division (2014). [Online]. Available: http://faostat3.fao.org/ home/E [1 September 2016].

3 Jukanti AK, Gaur PM, Gowda CL and Chibbar RN, Nutritional quality and health benefits of chickpea (Cicer arietinum L.): a review. Br JNutr 108:S11 -S26 (2012).

4 Mhadhbi $H$, Jebara M, Limam F and Aouani ME, Rhizobial strain involvement in plant growth, nodule protein composition and antioxidant enzyme activities of chickpea-rhizobia symbioses: modulation by salt stress. Plant Physiol Biochem 42:717-722 (2004).

5 Ramalho Ribeiro JMC and Portugal Melo IM, Composition and nutritive value of chickpea, in Present Status and Future Prospects of Chickpea Crop Production and Improvement in the Mediterranean Countries, ed. by Saxena MC, Cubero JI and Wery J. CIHEAM, Zaragoza, pp. 107-111 (1990).

6 Gaur PM, Tripathi S, Gowda CLL, Ranga Rao GV, Sharma HC, Pande $S$ et al., Chickpea Seed Production Manual. [Online]. International Crops Research Institute for the Semi-Arid Tropics (2010). Available: http://www.icrisat.org/TropicalLegumesll/pdfs/ChickpeaManual_ full.pdf [3 October 2016].

7 Mortimer PE, Pérez-Fernández MA and Velentine AJ, The role of arbuscular mycorrhizal colonization in the carbon and nutrient economy of the tripartite symbiosis with nodulated Phaseolus vulgaris. Soil Biol Biochem 40:1019-1027 (2008).

8 Xavier LJC and Germida JJ, Response of lentil under controlled conditions to co-inoculation with arbuscular mycorrhizal fungi and rhizobia varying in efficacy. Soil Biol Biochem 34:181 - 188 (2002).

9 Jensen ES, Peoples MB, Boddey RM, Gresshoff PM, Hauggaard-Nielsen $H$, Alves BJR et al., Legumes for mitigation of climate change and the provision of feedstock for biofuels and biorefineries: a review. Agron Sustain Dev 32:329-364 (2012). 
10 Köpke U and Nemecek T, Ecological services of faba bean. Field Crops Res 115:217-233 (2010).

11 Abera T, Semu E, Debele T, Wegary D and Kim H, Effects of faba bean break crop and $\mathrm{N}$ rates on subsequent grain yield and nitrogen use efficiency of highland maize varieties in Toke Kutaye, western Ethiopia. Am J Res Commun 3:32-72 (2015).

12 Glasener KM, Wagger MG, MacKown CT and Volk RJ, Contributions of shoot and root nitrogen-15 labeled legume nitrogen sources to a sequence of three cereal crops. Soil Sci Soc Am J 66:523-530 (2002).

13 Chalk PM, Souza R de F, Urquiaga S, Alves BJR and Boddey RM, The role of arbuscular mycorrhiza in legume symbiotic performance. Soil Biol Biochem 38:2944-2951 (2006).

14 Oliveira RS, Rocha I, Ma Y, Vosátka M and Freitas H, Seed coating with arbuscular mycorrhizal fungi as an ecotechnological approach for sustainable agricultural production of common wheat (Triticum aestivum L.). J Toxicol Environ Health A 79:329-337 (2016).

15 Farzaneh $M$, Vierheilig $H$, Lössl A and Kaul HP, Arbuscular mycorrhiza enhances nutrient uptake in chickpea. Plant Soil Environ 57:465-470 (2011).

16 Oliveira RS, Castro PML, Dodd JC and Vosátka M, Different native arbuscular mycorrhizal fungi influence the coexistence of two plant species in a highly alkaline anthropogenic sediment. Plant Soil 287:209-221 (2006)

17 Oliveira RS, Ma Y, Rocha I, Carvalho MF, Vosátka M and Freitas $\mathrm{H}$, Arbuscular mycorrhizal fungi are an alternative to the application of chemical fertilizer in the production of the medicinal and aromatic plant Coriandrum sativum L. J Toxicol Environ Health A 79:320-328 (2016).

18 Goicoechea N, Antolín MC and Sánchez-Díaz M, Gas exchange is related to the hormone balance in mycorrhizal or nitrogen-fixing alfalfa subjected to drought. Physiol Plant 100:989-997 (1997).

19 Goicoeechea N, Szalai G, Antolín MC, Sánchez-Díaz M and Paldi E, Influence of arbuscular mycorrhizae and Rhizobium on free polyamines and proline levels in water-stressed alfalfa. J Plant Physiol 153:706-711 (1998)

20 Schiermeier Q, Water: a long dry summer. Nature 452:270-273 (2008).

21 Ruiz-Lozano JM, Collados C, Barea JM and Azcon R, Arbuscular mycorrhizal symbiosis can alleviate drought induced nodule senescence in soybean plants. New Phytol 151:493-502 (2001).

22 Goicoechea N, Doléza K, Antolín MC, Strnad M and Sánchez-Díaz M, Influence of mycorrhizae and Rhizobium on cytokinin content in drought stressed alfalfa. J Exp Bot 46:1543-1549 (1995).

23 Ruiz-Lozano JM, Azcón R and Gómez M, Alleviation of salt stress by arbuscular-mycorrhizal Glomus species in Lactuca sativa plants. Physiol Plant 98:767-772 (1996).

24 Hardie K, The effect of removal of extraradical hyphae on water uptake by vesicular-arbuscular mycorrhizal plants. New Phytol 101:667-684 (1985)

25 Ruiz-Lozano JM and Azcón R, Hyphal contribution to water uptake in mycorrhizal plants as affected by the fungal species and water status. Physiol Plant 95:472-478 (1995).

26 Beringer JE, R factor transfer in Rhizobium leguminosarum. J Gen Microbiol 84:188-198 (1974).

27 Baláz $M$ and Vosátka $M, A$ novel inserted membrane technique for studies of mycorrhizal extraradical mycelium. Mycorrhiza 11:291-296 (2001).

28 Koide RT and Li M, Appropriate controls for vesicular-arbuscular mycorrhiza research. New Phytol 111:35-44 (1989).

29 Oliveira RS, Boyer LR, Carvalho MF, Jeffries P, Vosátka M, Castro PML et al., Genetic, phenotypic and functional variation within a Glomus geosporum isolate cultivated with or without the stress of a highly alkaline anthropogenic sediment. Appl Soil Ecol 45:39-48 (2010).

30 Grewal KS, Buchan GD and Tonkin PJ, Estimation of field capacity and wilting point of some New Zealand soils from their saturation percentages. NZ J Crop Hortic Sci 18:241 - 246 (1990).

31 AOAC, Official Methods of Analysis (18th edn). Association of Official Analytical Chemists, Gaithersburg, MD (2006).

32 FAO, Food Energy: Methods of Analysis and Conversion Factors. [Online]. Food and Agriculture Organization of the United Nations (2003). Available: http://www.fao.org/uploads/media/FAO_2003_Food Energy_02.pdf [3 October 2016].

33 Phillips JM and Hayman DS, Improved procedures for clearing and staining parasitic and vesicular-arbuscular mycorrhizal fungi for rapid assessment of infection. Trans Br Mycol Soc 55:158-161 (1970).
34 Oliveira RS, Vosátka M, Dodd JC and Castro PML, Studies on the diversity of arbuscular mycorrhizal fungi and the efficacy of two native isolates in a highly alkaline anthropogenic sediment. Mycorrhiza 16:23-31 (2005).

35 Giovannetti M and Mosse B, An evaluation of techniques for measuring vesicular arbuscular mycorrhizal infection in roots. New Phytol 84:489-500 (1980).

36 Brundrett M, Melville L and Peterson RL, Practical Methods in Mycorrhizal Research. Mycologue Publications, Waterloo, Canada (1994).

37 Tufenkci S, Sönmez F and Sensoy RIG, Effects of arbuscular mycorrhiza fungus inoculation and phosphorus and nitrogen fertilization on some plant growth parameters and nutrient content of chickpea. J Biol Sci 5:738-743 (2005).

38 Sohrabi Y, Heidari G, Weisany W, Golezani KG and Mohammadi K, Changes of antioxidative enzymes, lipid peroxidation and chlorophyll content in chickpea types colonized by different Glomus species under drought stress. Symbiosis 56:5-18 (2012).

39 Armada E, Azcón R, López-Castillo OM, Calvo-Polanco M and Ruiz-Lozano JM, Autochthonous arbuscular mycorrhizal fungi and Bacillus thuringiensis from a degraded Mediterranean area can be used to improve physiological traits and performance of a plant of agronomic interest under drought conditions. Plant Physiol Biochem 90:64-74 (2015).

40 Augé RM, Arbuscular mycorrhizae and soil/plant water relations. Can J Soil Sci 84:373-381 (2004).

41 Augé RM, Toler HD and Saxton AM, Arbuscular mycorrhizal symbiosis alters stomatal conductance of host plants more under drought than under amply watered conditions: a meta-analysis. Mycorrhiza 25:13-24 (2015).

42 Franzini Vl, Azcón R, Méndes FL and Aroca R, Different interaction among Glomus and Rhizobium species on Phaseolus vulgaris and Zea mays plant growth, physiology and symbiotic development under moderate drought stress conditions. Plant Growth Regul 70:265-273 (2013).

43 Hussain MB, Zahir ZA, Asghar HN and Asghar M, Can catalase and exopolysaccharides producing rhizobia ameliorate drought stress in wheat? Int J Agric Biol 16:3-13 (2014).

44 Oliveira RS, Castro PML, Dodd JC and Vosátka M, Synergistic effect of Glomus intraradices and Frankia spp. on the growth and stress recovery of Alnus glutinosa in an alkaline anthropogenic sediment. Chemosphere 60:1462-1470 (2005).

45 Sánchez-Romera B, Ruiz-Lozano JM, Zamarreño ÁM, García-Mina JM and Aroca R, Arbuscular mycorrhizal symbiosis and methyl jasmonate avoid the inhibition of root hydraulic conductivity caused by drought. Mycorrhiza 26:111-122 (2016).

46 Staudinger C, Mehmeti-Tershani V, Gil-Quintana E, Gonzalez EM, Hofhansl F, Bachmann G et al., Evidence for a rhizobia-induced drought stress response strategy in Medicago truncatula. J Proteomics 136:202-213 (2016).

47 Erman M, Demir S, Ocak E, Tüfenkçi ş, Oğuz F and Akköprü A, Effects of Rhizobium, arbuscular mycorrhiza and whey applications on some properties in chickpea (Cicer arietinum L.) under irrigated and rainfed conditions. 1. Yield, yield components, nodulation and AMF colonization. Field Crops Res 122:14-24 (2011).

48 Tavasolee A, Aliasgharzad N, Salehi GR, Mardi M, Asgharzadeh A and Akbarivala S, Effects of co-inoculation with arbuscular mycorrhizal fungi and rhizobia on fungal occupancy in chickpea root and nodule determined by real-time PCR. Curr Microbiol 63:107-114 (2011).

49 Zaidi A, Khan MS and Amil M, Interactive effect of rhizotrophic microorganisms on yield and nutrient uptake of chickpea (Cicer arietinum L.). Eur J Agron 19:15-21 (2003).

50 Pellegrino E and Bedini S, Enhancing ecosystem services in sustainable agriculture: biofertilization and biofortification of chickpea (Cicer arietinum L.) by arbuscular mycorrhizal fungi. Soil Biol Biochem 68:429-439 (2014).

51 Patterson CA, Maskus $\mathrm{H}$ and Dupasquier C, Pulse crops for health. Cereal Food World 54:108-112 (2009).

52 Donatelli M, Duveiller G, Fumagalli D, Srivastava A, Zucchini A, Angileri $V$ et al., Assessing Agriculture Vulnerabilities for the Design of Effective Measures for Adaption to Climate Change. [Online]. European Commission (2012). Available: http://ec.europa.eu/agriculture/externalstudies/2012/avemac/full-text_en.pdf [3 October 2016]. 